IRSH 66 (202I), pp. I39-I60 doi:I0.1017/S002085902 I00017I

(C) The Author(s), 2021. Published by Cambridge University Press on behalf of the Internationaal Instituut voor Sociale Geschiedenis. This is an Open Access article, distributed under the terms of the Creative Commons Attribution licence (http:// creativecommons.org/licenses/by/4.o/), which permits unrestricted re-use, distribution, and reproduction in any medium, provided the original work is properly cited.

\title{
"Fraudonomics": Cartooning against Structural Adjustment in Togo
}

\author{
R O B IN FRIS C H* \\ University of Bayreuth \\ D-95440 Bayreuth, Germany
}

E-mail: robin.frisch@uni-bayreuth.de

\begin{abstract}
This article offers a sensitive reading of oppositional political cartoons in Togo in the early I990s, during the period of structural adjustment, which was accompanied by the swift reversal of democratizing trends and the restoration of authoritarian rule. Togolese satirists perceived this moment as a moment of "fraudonomics", thus contesting rampant corruption and clientelism in politics. They poked fun at the president, local politicians, businesspeople, and bureaucrats of the international institutions. The article begins by examining the making of satirical newspapers with a focus on the biographies of the satirists. As students, they started out on the adventure of publication with their own money and learned most of their drawing and printing techniques as work progressed. Secondly, an analysis of the readership shows that, although the satirical newspapers were a crucial element of the media in the early i 990s, it was mostly an elitist and urban phenomenon. The third section analyses the changing visual repertoire of contention through in-depth analysis of four selected caricatures.
\end{abstract}

In I982, Togo began its structural adjustment programmes (SAPs). By i989, the country had entered its fourth round of restructuring, and the privatization and austerity measures were taking place alongside widespread street demonstrations. Student protests and strikes led to a National Conference, which enabled opposition politicians to openly criticize President Eyadéma's regime for the first time in decades. The government had stopped hiring graduated students and could hardly afford to pay workers' salaries. For this reason, students and workers were at the forefront of these mobilizations.

\footnotetext{
* I am sincerely grateful for the comments from colleagues at the African History Research Seminar at the University of Bayreuth as well as during the workshop on this Special Issue at the International Institute of Social History in Amsterdam. My special thanks go to the team of Kpakpa Désenchanté for authorizing the reprint of the cartoons and allowing me to delve into the world of Togolese satire.
} 
Nonetheless, Togo's National Conference failed. Soldiers forcefully broke it apart, and Eyadéma, who had been in power since 1967, remained in office. The political and economic crises were inherently connected. Reports by the International Monetary Fund (IMF) documented the effects of this "civil unrest" as a "serious economic disruption", "virtual standstill", and "economic paralysis". ${ }^{\mathrm{I}}$ For the IMF, the protests signalled "political disturbances" that would harm Togo's economic performance. ${ }^{2}$ Yet, the question is how the protesters themselves perceived the adjustment.

Research on protest in West Africa during the I990s has focused primarily on democracy and on the effects of the structural adjustment. ${ }^{3}$ Modernization theorists tried to explain the conditions of democratization and insisted that economic factors were key. ${ }^{4}$ Dependency theorists took the counterposition and criticized the importation of democracy models by emphasizing external domination. ${ }^{5}$ Both approaches offer a rather teleological and determinist vision of political change. By focusing mainly on institutions, which tends to over-emphasize the power of elites, these perspectives rarely took into consideration the political sensitivities and changing representations in the moment of political protest. Besides these two major research frameworks for African politics, more works inspired by sociology highlight the multiple forms of contention. ${ }^{6}$ Comi Toulabor and Stephen Ellis have shown that rumour and humour were important channels of expression in the Togolese political culture. ${ }^{7}$ Although President Eyadéma controlled the media of the one-party dictatorship, he was still ridiculed through hidden messages in songs, wax prints, or even banknotes. However, few researchers have engaged with the role of satire and contention within the context of democratization and structural adjustment in Togo.

I. Saleh Nsouli, "Structural Adjustment in Sub-Saharan Africa", Finance and Development, 30 (1993), pp. 20-23, 20; International Monetary Fund (hereafter IMF) "Recent Economic Developments”, Staff Country Report Togo, 94 (Washington, DC, I994), p. I I 3, I.

2. IMF, "Recent Economic Developments", p. 5 .

3. Lisa Mueller, Political Protest in Contemporary Africa (Cambridge, 2018), p. 263.

4. Benno Ndulu and Stephen O'Connell, "Governance and Growth in Sub-Saharan Africa", Journal of Economic Perspectives, I 3 (1999), pp. 4I-66, 42. For an excellent discussion of research on democratization, see Nicolas Van De Walle, "Démocratisation en Afrique. Bilan critique”, in Céline Thiriot and Mamoudou Gazibo (eds), Le Politique en Afrique. Etat des débats et pistes de recherche (Paris, 2009), pp. I35-163.

5. Van De Walle, "Démocratisation en Afrique", pp. I35-163, I42-144.

6. Richard Banégas, La démocratie à pas de caméléon. Transition et imaginaires politiques an Bénin (Paris, 2003), pp. 8-27; Vincent Bonnecase, Les prix de la colère (Paris, 2019), p. 28I; Achille Mbembe, De la postcolonie. Essai sur l'imagination politique dans l'A frique contemporaine, (Paris, 2000), p. 256; Johanna Siméant, "Protester/mobiliser/ne pas consentir. Sur quelques avatars de la sociologie des mobilisations appliquée au continent africain”, Revue internationale de politique comparée, 20 (2013), pp. I25-I43.

7. Comi Toulabor, Le Togo sous Eyadéma (Paris, 1986), p. 322; Stephen Ellis, "Rumour and Power in Togo", Africa, 63 (1993), pp. 462-476. 
The article addresses this lacuna and investigates how oppositional satirical newspapers portrayed the political and economic transformation. As the article will show, these mobilizations of the early i 990 s were far from only being about structural adjustment or democracy. The satirical category of "fraudonomics" provides a useful lens through which one can examine the various representations of adjustment from the cartoonists' perspective. "Fraudonomics" is a pun that was invented by cartoonists of the first Togolese satirical newspaper La Parole, to denounce fraud, corruption, and injustice. It allows for the criticism of fraud not only in the economic sphere, but also in the political domain, where electoral malpractices and corruption were rampant. Fraudonomics was a highly moralizing form of critique. This "repertoire of contention" contains deliberately subjective and moral perspectives, rather than neutral information. ${ }^{9}$ For this group of journalists, who were mainly students active in the demonstrations of the early I990s, fraudonomics was a counter-discourse to the language of the adjustment and of the regime. E.P. Thompson, in his work on the moral economy of English workers, showed that specific events and "economic stimuli" did not mechanically trigger protests. ${ }^{10}$ Rather, protests are the expression of historic injustices or sensitivities, and representations of what is right or wrong. In line with the concept of the moral economy of protest, this article argues that the Togolese satirical newspapers opened a space for political and economic alternatives.

Political cartoons are a paradoxical form of representation. They are simplistic, yet complex. They dramatize realities, yet also de-dramatize them. Georg Simmel saw in caricatures a transgressive and boundary-searching way of being. They are distortions of reality, anti-forms, and deliberate productions of unreality. ${ }^{\text {II }}$ Cartoons only work through exaggerated information, but they are an effective way of capturing rumours and uncovering subjective realities. In Togo, cartoons fulfilled an important need for a liberated form of criticism at a time of acute political disorientation. Furthermore, for historical research, they provide a way to break through the artificial dichotomy of

8. The original term in French was "escrocs-nomie" [Fraudonomics] and appeared as a rubric in La Parole (Lomé, Togo) from 1990 to 1992.

9. Charles Tilly, Regimes and Repertoires (Chicago, IL, 2006), p. 240. For a discussion of the concept in this review, see Marcel Van der Linden, "Charles Tilly's Historical Sociology", International Review of Social History, 54 (2009), pp. 237-274, 240 of.

Io. E.P. Thompson, "The Moral Economy of the English Crowd in the Eighteenth Century", Past E Present, 50 (197I), pp. 76-1 36. See also Vincent Bonnecase, Les prix de la colère (Paris, 2019), pp. 8-30.

I I. Georg Simmel, Über die Karikatur. Zur Philosophie der Kunst, vol. I3 (Berlin, I922), p. 248. On the role of political cartoons in Africa, see Jean-Pascal Daloz, "Les ambivalences dans la caricature des dirigeants politiques. Illustrations africaines”, Mots, 48 (1996), pp. 74-86; Achille Mbembe "La 'chose' et ses doubles dans la caricature camerounaise", Cahiers d'Études africaines, 36 (1996), pp. I 43-170; Marie-Soleil Frère, Presse et démocratie en Afrique francophone. Les mots et les maux de la transition au Bénin et au Niger (Paris, 2000), pp. I6I-488. 
fact and arbitrariness. They are not only a form of protest or sedition, but also a visual archive of the protest. ${ }^{\mathrm{I} 2}$ By analysing political cartoons published in Togolese satirical newspapers from I 990 to 1996 , this case study provides a closer understanding of the changing moral economy of protesters during this period.

The corpus of analysis contains a sampling of three satirical newspapers that were published between 1990 and 1996. La Parole (1990-1993), La Pagaille (1991-I992), and Kpakpa Désenchanté (I991-1996) were published weekly in tabloid format and generally each contained about ten pages. At the height of the public debates during the period of the National Conference, La Parole sold i 5,000 copies, while Kpakpa Désenchanté and La Pagaille usually printed around 5,000 copies. ${ }^{13}$ As this article will show, these numbers are not representative of the entire readership, since some readers did not purchase their own newspapers but copied them or cut out individual articles. The satirical newspapers were an important part of the media that were covering the ongoing political changes. It was the first time for decades that the government had allowed the liberalization of the press. Togolese people no longer had to read or watch Eyadéma's propaganda media. While student demonstrations were taking place, reading the free press, which openly poked fun at the president, was a liberating experience.

In the aftermath of the National Conference, journalists chose not to focus only on the autocratic Eyadéma, but instead to pose wider questions regarding the foundations of the political and economic system. The cartoons depicted World Bank and IMF officials, businesspeople, and trade unionists side by side with Togolese politicians. This, in turn, offered a multilayered reading. For example, the differing contents of the speech and thought bubbles contrasted the dissonance between overt and covert intentions. Another frequent cartooning device was the animalization of persons. By turning the human characters into dogs, frogs, or gorillas, the satirists invented a world of politics that resembled George Orwell's Animal Farm. ${ }^{\mathrm{I} 4}$ The newspapers produced and reproduced protest slogans. These images, metaphors, and symbols were well-known references in the Togolese protest culture. As a highly codified way of communication, they strengthened the group identification of protesters, yet might also have excluded large parts of society who were less familiar or opposed to these messages.

I2. The reflection of the role of satire, especially of humour in social protest, is inspired by an earlier discussion in this journal, see Marjolein 't Hart, "Humour and Social Protest: An Introduction", International Review of Social History, 52 (2007), pp. I-20.

I3. Concerning the numbers of sold copies, see Dieudonné Korolakina, "Togo. Du ludique au politique", Africultures, 79 (2009), pp. 62-69, 67. This research is primarily based on the volumes that are accessible at the Archives Nationales du Togo (hereafter ANT). Further information was collected through eight interviews with journalists and cartoonists at Lomé (August 2019), Cotounou (September 2019), Paris (March 2020), and Bayreuth (March 2020).

14. George Orwell, Animal Farm: A Fairy Story (London, 1945), p. I I 2. 
The first section of this article examines the making of the newspapers by focusing on the biographies of the satirists. As student activists, this small group of journalists and cartoonists embarked upon the adventure of publication with their own money and learned most of the drawing and printing techniques on their own. Secondly, this article discusses the reception of the cartoons as a form of collective reading. An analysis of the readership will show that, although the satirical newspapers were a crucial part of the media at a specific moment in the early I990s, it was mostly an elitist and urban phenomenon. The third section analyses the changing visual repertoire of contention through in-depth analysis of four selected caricatures.

\section{THE MAKING OF THE CARTOONS}

Many of the satirical journalists had similar biographies. The founders of Kpakpa Désenchanté, Selom Gbanou and Knock Kalao Billy, studied together through high school and university. They were politically engaged in the Groupement de réflexion et d'action pour la démocratie, which was a prodemocratic student organization created in 1989 . They had close ties to leading opposition politicians such as Joseph Koffigoh and Yawovi Agboyibo, who both later became prime ministers. For the young students, their philosophy classes coupled with charismatic teachers were a significant source of inspiration. The Propos scientifique, a journal by philosophy professors at the University of Lomé that was first published in the I980s, provided the students with their first editorial experience, albeit without the tools of humour and caricature.

A number of influences shaped the Kpakpa Désenchanté style. The cartoonist Hector Sonon imitated the drawings of the French newspaper Canard Enchaine. ${ }^{\text {Is }}$ Publications such as Jeune Afrique or the Cafard Libéré from Senegal provided external information on the regime. Furthermore, Western cultural institutes such as the Goethe-Institut and Institut Français offered safe havens for the critical journalists. Their satirical activism created a sense of familial conviviality for the journalists, and they developed deep emotional ties to each other that exist to this day. ${ }^{16}$ This intimacy arose not only from their shared activism, but also from their precarious work conditions. They often feared for their lives and took radical measures to protect themselves, such as the use of pseudonyms, fake identity cards, and the avoidance of public spaces.

The satirical press was an indirect result of the adjustment measures. Employment opportunities for students were reduced significantly owing to the privatization of state-owned companies, as well as the restructuring of

I 5. Interview with Hector Sonon, Cotonou, September 2019.

I6. Interview with Knock Kalao Billy, Paris, March 2020. 
the public administration through the suspension of recruitment. ${ }^{17}$ The economic policies produced a new generation of politically and economically frustrated youth. The "jeunes conjuncturés", with their good university degrees but few opportunities in the disintegrating job market, were at the heart of the protests in the $1990{ }^{18}{ }^{8}$ In this way, some of the cartoons depicting the harsh realities of Togolese citizens were not merely abstract or exaggerated discourse, but the actual lived experiences of the young journalists. In the context of punishing financial conditions, cartooning was not only an organized strategic political act, but also a pragmatic way to earn some desperately needed money. Despite the financial difficulties, it is remarkable that Kpakpa Désenchanté could function entirely from sales revenue, without relying on advertisements. ${ }^{\text {I9 }}$

Following their first editorial experiences at La Parole, the journalists regrouped and founded their own publication in 1991. According to the chief editor, Selom Gbanou, the idea to create Kpakpa Désenchanté came to them in 1985 . The first issues were artisanal in nature, with much improvisation and hand-cutting involved. The budget was tight. Students would even participate in pro-Eyadéma demonstrations in order to receive the money that was distributed and channel it into their newspaper. ${ }^{20}$ Kpakpa Désenchanté became a "lighthouse" in the Togolese press landscape. ${ }^{21}$ Soon, other newspapers such as Le Crocodile and La Pagaille imitated its satirical style. The journalists identified themselves as the "safeguards of the opposition" and the "moles against the government". Owing to "friends on the government side", the journalists could hide when it was time to go to the commissariat again. Having allies in the ministries and even in the presidential office allowed them more room for manoeuvre and better access to information. Being able to operate with near autonomy was new in the Togolese context of repression, where for decades the one-party regime had controlled the media. Prior to this time, journalists mainly served the propaganda machine or were forced into exile. ${ }^{22}$

During the I990s, the press became a serious watchdog of the state. Knock Kalao Billy remembered that one police officer lamented "these ducks

17. Komlan Kwassi Agbovi, “Les incidences sociales des programmes d'ajustement structurel et de la dévaluation sur les populations urbaines du Togo” (Ph.D., Université de Lomé, 2003), pp. I-75.

I8. Comi Toulabor, "L'énonciation du pouvoir et de la richesse chez les jeunes 'conjonctures' de Lomé (Togo)”, Revue française de science politique, 3 (1985), pp. 446-458.

19. L'Humanité (Paris, France), 24 February 1993, Claude Kroes, “'Kpakpa' veut continuer de paraitre”. Available at https://www.humanite.fr/node/5050I; last accessed 25 April 2020.

20. Interview with Knock Kalao Billy, Paris, March 2020.

2 I. Interview with Selom Gbanou, Bayreuth, March 2020. The following quotations are from the same interview.

22. Essohanam Batchana, Liberté de presse et pouvoirs publics an Togo. 1946-2004 (Ph.D., Université de Lomé, 2008), pp. 250-300. 
[referring to Kpakpa Désenchanté] leave their excrement everywhere". ${ }^{23}$ The quality and depth of the journalism improved significantly. The first satirical newspaper, La Parole, reported on Togolese politics by primarily focusing on Eyadéma. Kpakpa Désenchanté had a much wider scope, also covering economic and cultural topics. The general style of the satirical newspapers shifted from a firmly anti-Eyadéma position to a broader investigative journalism. During the National Conference, the journalists' intention was to give voice to the unheard and oppressed opinions. Publishing a newspaper had become a way to cope with the memories of a decade-long dictatorship. In I99I, the journalists' major interest was not reconciliation, as was intended by some participants of the National Conference. ${ }^{24}$ Above all, they wanted truth. However, watchdog journalism was still in the making, and it was difficult to uncover fraud in a system that had a high level of press censorship and state intervention.

Satire as a channel of political communication was not only new for the journalists, but also for the readers. Some cartoons had staggering emotional depth, even when all they did was make a quick and cynical joke. Although these emotions were shrouded in sarcasm, the anger, frustration, and sadness were ever present. Even so, the imagery of the cartoons was never unsubtle. The newspapers were printed on thin paper and were a much more ephemeral and low-cost medium than theatre, film, or novels. The journalists signed themselves with pseudonyms, such as "Emmerdeur" (Troublemaker), "En Mangeant" (While Eating), and "L'Enragé" (The Furious). ${ }^{25}$ Publishing anonymously was a way to protect one's identity and lower the risk of prosecution. The cartoonists' fictitious names, such as "Catirerisq" (Satire-risk) and "Sansracune" (Without Rancour), were in line with the sarcastic style. There was not a single person behind each pseudonym, but a collective authorship. In the same way, several cartoonists worked on the same drawing. ${ }^{26}$ Mocking the dapper-suited politicians, the "elders", and all other powerful persons created a simple but strong and protective identity, a "we" against the "they" of the dominating regime.

Cartooning emerged historically as a hybrid that drew on different forms of protest. During the 1980 , the publication of the propaganda graphic novel $\mathrm{Il}$ était une fois Eyadéma dominated the visual culture of Togolese politics. This hugely popular "bande dessinée" portrayed an invented biography of

23. Interview with Knock Kalao Billy, Paris, March 2020. In Èvegbe, the word kpakpa means "duck".

24. On the National Conference in Togo, see John Heilbrunn, "Social Origins of National Conferences in Benin and Togo", The Journal of Modern African Studies, 31 (1993), pp. 277299; Kathryn Nwajiaku, "The National Conferences in Benin and Togo Revisited", The Journal of Modern African Studies, 32 (2014), pp. 429-447.

25. Signatures of journalists collected in Kpakpa Désenchanté and La Parole.

26. Korolakina, "Togo. Du ludique au politique”, p. 66f. 
Eyadéma. ${ }^{27}$ The disenchanted cartoons of the I990s challenged this legend and portrayed the president in every possible way as weak, untrustworthy, and even inhuman. ${ }^{28}$ Their novelty consisted in their use as part of the repertoire of contention. Before the I990s, cartoons never represented critical political speech. Political leaflets (or tracts), hitherto the main channel of contestation, inspired the short editorials that were published alongside the cartoons.

Because of their intellectual backgrounds, the cartoonists and journalists could be considered an avant-garde category within the Togolese protests. The newspapers were produced mainly in French by highly educated, urban groups. For this reason, the cartoons in the satirical press were far from being a subaltern story, but rather were "messages from the elite for the elite". ${ }^{29}$

\section{COLLECTIVE READING}

Political cartoons rapidly became one of the most persuasive tools of political communication in the I990s. The success of this medium would not have been possible without the technological progress of printing technology and its increasing accessibility at Lomé. The official sales numbers must be taken with a pinch of salt, however, as print shops often secretly produced more in order to increase their own profits. ${ }^{30}$ Moreover, the readership was much wider than the figures show, as "approximately ten people read one newspaper" ${ }^{3 \mathrm{I}}$ Knock Kalao Billy, the editor-in-chief, remembers that cartoons were often cut out and pasted onto walls, including those of police stations. Police officers, gendarmes, and ministers were frequent readers of Kpakpa Désenchanté. Surprisingly, regime-loyal politicians such as Colonel Damehane Yark, today's much-feared Minister of Civil Security, were enthusiastic readers of Kpakpa Désenchanté. President Eyadéma allegedly had four subscriptions. ${ }^{32}$ According to the journalists, most soldiers and police officers were not opposed to the satire and were, in fact, among their most loyal readers.

27. Serge Saint-Michel, Histoire du Togo. Il était une fois Eyadéma (Paris, 1976), p. 48. For a critical discussion of the propaganda comic, see Selom Gbanou, "En attendant le vote des bêtes sauvages ou le roman d'un 'diseur de vérité”, Études françaises, 42 (2006), pp. 5I-75, 55.

28. Figures $\mathrm{I}$ and 4 in this article. See also Korolakina, “Togo. Du ludique au politique”, pp. $65-$ 69,65 .

29. Frère, Presse et démocratie, p. 256.

30. Interview with Knock Kalao Billy, March 2020, Paris. For a discussion of the distribution of independent newspapers in Togo, see Mikaila Saibou, "Crise de la presse imprimée en Afrique à l’ère du numérique” (Ph.D., University of Lomé), p. 4I.

3I. Interview with Knock Kalao Billy, March 2020, Paris.

32. Ibid. 
Civil servants were one of the most important groups that bought the satirical press. However, in the shaky adjustment economy, their salaries were paid irregularly. Readers and vendors were therefore forced to devise new forms of distribution. Making copies or "renting" the newspapers increased the readership. ${ }^{33}$ News and cartoons were shared by the street hawkers who were selling the newspapers "à la criée". ${ }^{44}$ The collective reading and sharing, and the street gossip that it elicited, was an important part of political debate. The satirical press was read not only by government ministers, but also by market traders and even those who could not read the editorials but nonetheless could laugh at the humorous caricatures. ${ }^{35}$

It is extremely difficult to reconstruct readers' reactions as scrutiny today can hardly capture the complexities of the situation. Marie-Soleil Frère has shown, in the case of the independent press in Niger and Benin, that journalists did not express the "popular voice" they claimed to represent. In the Togolese case, the readership was also mostly urban and elite groups. The satirical press was more a "class media" than a "mass media". ${ }^{6}$ The reasons for the shrinking readerships at the end of the I990s were the rising frustrations with Togolese politicians as well as the people's general disappointment in the press.

The regime's answer to the critical press involved an ambiguous policy of limited liberalization and censorship. Knock Kalao Billy was imprisoned and interrogated several times at a police station. In some cases, journalists were conscripted by the regime. For example, in 1992, the editor of $L a$ Pagaille switched allegiance in favour of RPT (Rassemblement du Peuple Togolais), the president's party. ${ }^{37}$ The relative liberalization of the press proved to be only a brief episode, and most newspapers soon collapsed owing to financial difficulties and physical intimidation by the regime. Repression began to take new forms, such as limiting access to printing technology and restricting access to paper. ${ }^{38}$ The regime employed informants within the print shops, who were required to leak prospective publications to the authorities. Some of the print shops were also targeted and burned. ${ }^{39}$

According to Selom Gbanou, the abrupt end of most satirical newspapers was not necessarily because of repression by the regime, but the political disillusionment and personal "disenchantment" of the people. He notes that: "We tried to change the political spirit. It was a big dream to be the avant-garde

33. On the distribution in the streets, see Frère, Presse et démocratie, p. 444.

34. Interview with Knock Kalao Billy, March 2020, Paris.

35. Interview with Selom Gbanou, Bayreuth, March 2020.

36. Frère, Presse et démocratie, p. 475.

37. Saibou, "Crise de la presse imprimée", p. I79.

38. See the general discussion by Paul Nugent in Africa Since Independence (London, 2012), p. 39I.

39. Interview with Abass Saibou, Lomé, September 2019. Signe, Al-Agah, and Todegnon, the most important printing houses for the opposition press, were destroyed. 
of critical journalism. At the end, one can say that it was a little naïve. Maybe we had some social or intellectual impact. But politically, we did not achieve anything." 40 This finding confirms research on humour in authoritarian regimes, which uncovered the fact that satire can serve the dominating actors as a legitimizing tool. To a certain extent, criticism might stabilize a political regime. Achille Mbembe and Jean-Pascal Daloz have shown, in the case of Cameroon, that depictions of the autocratic ruler reinforced his presence in the public sphere. ${ }^{41}$

\section{“NATIONAL CONFERENCE OR NATIONAL CORRUPTION?”}

Eyadéma was profoundly destabilized during the National Conference, which was held between 8 July and 28 August 1991. The deputies proclaimed sovereignty and proposed a transitional government. Even though Eyadéma rejected this and did not participate in the conference, the ongoing economic crisis significantly challenged his financial sovereignty. ${ }^{42} \mathrm{He}$ lost control over the state's financial affairs because the party's accounts were frozen and the Public Treasury was no longer administered by the regime. For decades, these institutions had been used as mechanisms of kleptocracy.

Published just two days after the opening of the National Conference, the cartoon reproduced as Figure I shows a grimacing Eyadéma, his face half in shadow, distributing money into the hands of unknown people. The caption reads "National Conference of National Corruption?" Eyadéma is saying, "I am honest. I am bribing you with the cash that I stole from you!" The president is loaded with so much money that it is even pouring out of his ears. The cartoon hints at the exaggerated amounts of money that Eyadéma is holding and the perverted manner of its distribution. It also evokes his self-chosen business suit uniform. The cartoon attests to the change of his political image from military khaki to a Western double-breasted business suit. ${ }^{43}$ This outfit was meant to counterbalance the image of the "uncivilized murderer" that was attached to his military uniform, following his boastful remarks over the killing of Silvanus Olympio. ${ }^{44}$ The image of a businessfriendly, capitalist-oriented president changed his standing in the international arena of business and donors.

40. Interview with Selom Gbanou, Bayreuth, March 2020.

4I. Daloz, "Les ambivalences dans la caricature”, pp.74-86, 85 ; Mbembe, "La 'chose' et ses doubles", pp. I43-170, I69.

42. See Heilbrunn, "Social Origins of National Conferences", pp. 277-299, 277; Nwajiaku, "The National Conferences", pp. 429-447, 43 I.

43. Ellis, "Rumour and Power", pp. 462-476, 464.

44. Ibid., pp. 462-476, 465 . 


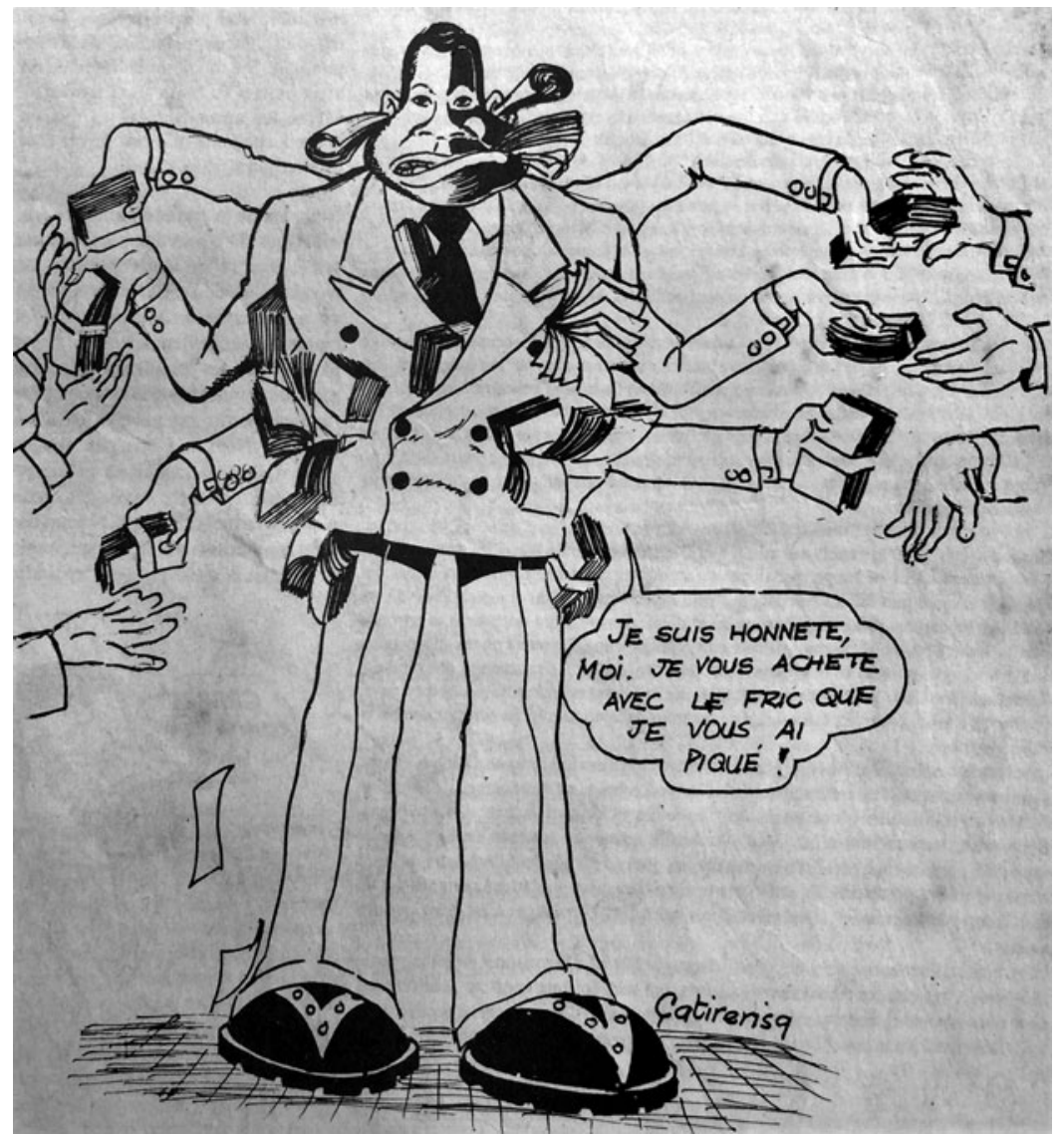

Figure I. "Conférence nationale ou corruption nationale?", La Parole (Lomé, Togo), ro July I99I, p. 2.

For decades, "all monies passed through Eyadéma's hands". ${ }^{45}$ The street murmurs of the "jeunes conjuncturés" often opposed his excessive luxury. Eyadéma was known for stashing 90 billion CFA francs in Swiss bank accounts. ${ }^{46}$ Some cartoonists surrogated the Public Treasury as "Lomé 2 ", which was the President's residence. Nonetheless, the "flight of Cold War monies, the fallout from the National Conference, and the effects of neo-liberalization" profoundly destabilized Eyadéma's kleptocracy. ${ }^{47}$

45. Charles Piot, Nostalgia for the Future: West Africa after the Cold War (Chicago, IL, 2010), p. 35 .

46. Comi Toulabor, "L'énonciation du pouvoir", pp. 446-458, 450; Toulabor, Le Togo sous Eyadéma, p. I 20.

47. Piot, Nostalgia for the Future, p. 34 . 
During the 1990s, the regime reinvented itself through a relentless process of regaining control over financial affairs. However, the privatization of public companies and the creation of non-governmental organizations (NGOs) made it difficult for money to be controlled centrally the way it had been done for decades in the one-party state. The capital of NGOs or the money created by relationships with foreign businesses circumvented the national treasury and went directly into the pockets of state employees, "with the result that Eyadéma and his clients skimmed less and less". ${ }^{48}$ Cartoons of this period depicted Eyadéma standing in the shadows, referencing the shadow relations of politicians and businessmen. The international perception of Togo as "Africa's Switzerland" gained another connotation during these days. ${ }^{49}$ Usually, this label referred to the "laissez-faire attitude" of the government and Lomé as a regional banking centre. ${ }^{5 \circ}$ As Figure I metaphorically indicates, Togo became a "shadow state" under Eyadéma. James Ferguson formulates a similar diagnosis of state officials in "weak states", losing power in official politics, but gaining influence through private and illicit networks. Numerous studies on African states in this period have shown how "big men" accumulated considerable wealth and power despite institutional decay during the adjustment. ${ }^{\text {I }}$

After the National Conference, political assassinations became extremely frequent. Soldiers even attacked Prime Minister Koffigoh on 3 December 1991. At the beginning of 1992, it was clear to Kpakpa Désenchanté that Eyadéma would restore power by using physical violence. The editorial of 7 July 1992 announced that "INSECURITY is guaranteed for $200 \%$ " this year. It was in 1992 that violence became widespread and even banal. The "tiny democratization" was interrupted by various political assassinations, such as the May 1992 attack on opposition leader Gilchrist Olympio and the July 1992 murder of politician Tavio Amorin. ${ }^{52}$ In the former attack, which was organized by Eyadéma's son Ernest Gnassingbè, twelve people were killed. ${ }^{53}$ The satirical press covered these events extensively, depicting a

48. Ibid., p. 43 .

49. Colleen Lowe Morna, "Africa's Switzerland?”, Africa Report, 9 (1990), pp. 35-38.

50. Morna, "Africa’s Switzerland?", pp. $35-38,36$.

5. James Ferguson, Global Shadows: Africa in the Neoliberal World Order (Durham, NC, 2006), p. I5; William Reno, Corruption and State Politics in Sierra Leone (Cambridge, I995); see also the outstanding analysis by Jean-Francois Bayart, State in Africa: The Politics of the Belly (Cambridge [etc.], 2009).

52. John Heilbrunn and Comi Toulabor, "Une si petite démocratisation pour le Togo...", Politique africaine, 58 (1995), pp. $85-100,85$.

53. Koffi Nutefé Tsigbé, "La presse satirique face aux assassinats politiques au Togo en 1992. Quel crédit pour l'historien? Les exemples de La parole et Kpakpa désenchanté”, Esboços. Histórias em contextos globais, 25 (2018), pp. 68-87, 79. 
martyred Amorin, or Gilchrist Olympio surviving only because of the protection offered by his father's spirit. ${ }^{54}$

In this context, various cartoons not only depicted political violence, but also the daily sufferings during the economic crisis. They referred to the violence of fraudonomics as a combined burden. The satire hardly distinguished between the effects of Eyadéma's violent restoration of power and the harsh economic measures. Workers, whose salaries were cut, were illustrated as floating in saucepans. Consumers were depicted as having malnourished bodies collapsing under the unbearable weight of "heavy" politicians or of symbols showing rising prices. ${ }^{55}$ This macabre sarcasm indicates the feeling that economic reforms had "inhuman" consequences. In the late I980s, international organizations became more aware of the social consequences of adjustment and poverty alleviation. The International Labour Organization and UNICEF advocated for an adjustment with a "human face". ${ }^{6}$ The satirical newspapers parodied this concept by alluding to the World Bank and IMF officials as "merchants of death" or the "adjustment struct-cruel".57

Figure 2 shows a conversation between the US president George H.W. Bush and President of the World Bank, Jeremy Preston. Bush asks Preston about the "big decisions of the World Bank". According to him, the "biggest decision of the World Bank is to get rid of these dictators who are only investing in weapons". ${ }^{8}$ The Togolese army was crucial to the Eyadéma's authoritarian restoration of power during the post-Cold War era. Indeed, General Eyadéma used loyal soldiers to disrupt the National Conference. Moreover, "he increased the size of the military [...] and multiplied the number and types of military units".59 After the political assassinations and the violent repression of demonstrations, imposing the president's legitimacy through ethnic warriorhood and a martial cult seemed outdated. In contrast to the propaganda narrative of the army as a peaceful, unifying, and stabilizing force, the cartoonists perceived militarization as a serious threat. Eyadéma spoke about the army as the "backbone of the Togolese nation". ${ }^{60}$ The satirical newspapers denounced this "military-nation" and reported that the Forces

54. See Tsigbé, “La presse satirique”, pp. 68-87, 70f. Gilchrist Olympio's father, Togo’s first president, Silvanus Olympio, was assassinated in 1963 . Eyadéma himself claimed responsibility for it. See Kate Skinner, "West Africa's First Coup: Neo-Colonial and Pan-African Projects in Togo's 'Shadow Archives'”, African Studies Review, 39 (2019), pp. I-24, 2.

55. Kpakpa Désenchanté (Lomé, Togo), I 2 December 1995, p. 3; Kpakpa Désenchanté (Lomé, Togo), 20 June i995, p. I.

56. Richard Jolly, "Adjustment with a Human Face: A UNICEF Record and Perspective on the I980s”, World Development, I9 (1991), pp. I807-182 I, I808.

57. Forum Hebdo (Lomé, Togo), I February i99i, p. 3. [Marchands de mort], Kpakpa Désenchanté (Lomé, Togo), i6 November 1993, p. I (ajustement strut-cruel).

58. La Parole (Lomé, Togo), 23 December I991, p. 6.

59. Piot, Nostalgia for the Future, p. 36.

60. Toulabor, Le Togo sous Eyadéma, pp. 95-99. 


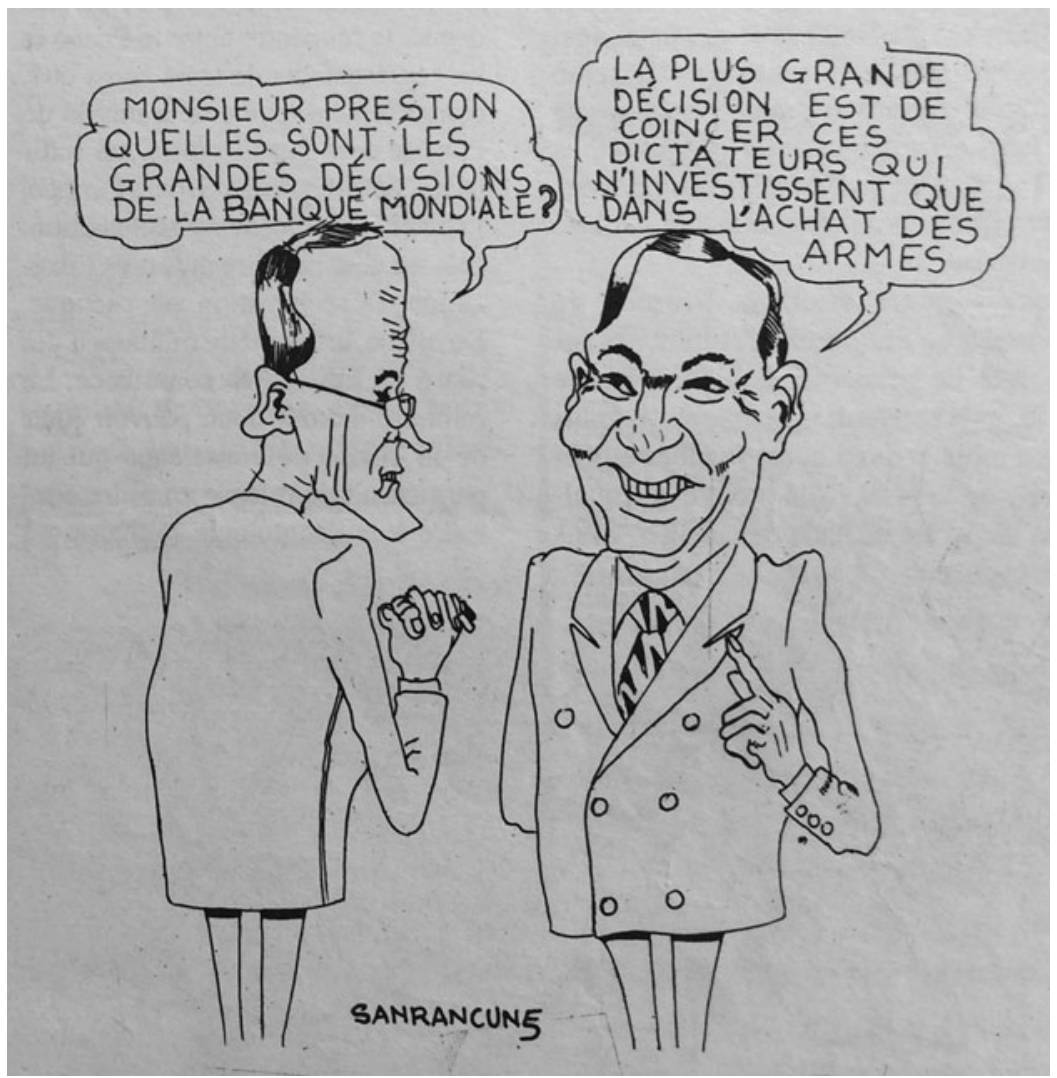

Figure 2. “Les grandes décisions de la Banque Mondiale”, La Parole (Lomé, Togo), 23 December I99I, p. 6.

Armées Togolaises were primarily responsible for the failure of the National Conference. ${ }^{6 r}$

The cartoon also hints at the Western states' hypocrisy in the support of political change. Preston's wry smile, raised finger, and one hand hidden behind his back all imply the hatching of a ruse. The cartoon not only underscores Eyadéma's system of fraudonomics on the national level, but also hypocrisy at the international level. The cartoonists illustrate the structural adjustment as a high-level diplomatic negotiation between US politicians. In reality, Bush and Preston probably never talked about Eyadéma's arms deals. However, this invented dialogue reveals what the structural adjustment was about for the cartoonists. Instead of depicting negotiations between

6r. On the "military-nation", see Tsigbé, "La presse satirique", pp. 68-87, 74. 
bureaucrats, which involve reports, evaluations, and consultancy, the conversation between Bush and Preston appears to be informal. This representation of high-level decisions involving tricks and traps is an expression of fraudonomics. The cartoonists questioned the trustworthiness of all politicians and economists.

In Figure 3, Eyadéma, again in his double-breasted business suit, listens to Michel Camdessus, the managing director of the IMF, who proclaims "drastic, bitter, inhuman and devastating measures for the economic recovery". Prime Minister Koffigoh hides behind the wall as he hears the president saying he wants to fire all the "boulotteurs inutiles" [useless eaters]. The cartoon refers to the idea of the prime minister as a scapegoat for the increasingly unpopular structural adjustment. The tension between Koffigoh and Eyadéma was high since he was the first prime minister of the transitional government and one of the protagonists of the National Conference. Nevertheless, soldiers humiliated Koffigoh in an overnight coup in December 1991. He stayed in office, but lost most of his credibility. Even the journalists who worked with him during the National Conference no longer supported him. Consequently, he became a "useless eater" of public funds. Ironically, the cartoon presents IMF Director Camdessus as an ally in Eyadéma's "politics of the belly". Jean-Francois Bayart conceptualized this idiomatic expression as an unequal accumulation of power and wealth by the elite. This model draws attention to the illicit or corrupt methods that "big men" use to acquire capital. ${ }^{62}$ In this case, the cartoonist draws Eyadéma in a typical gatekeeping role. The president choses personally, similar to the portrayal in Figure I, how he wants to distribute the aid of the financial institutions.

Most of the cartoons published from I 990 to 1992 blamed the government but not the international institutions. This changed after the National Conference and the failing democratic transition. After a decade of adjustment, the newspapers increasingly criticized the IMF and the World Bank. In August 1993, Eyadéma won the first presidential election after the National Conference through the massive use of fraud. For most of the observers and analysts, this election was a masquerade or an "electoral embarrassment" ${ }^{63}$

Once more, this representation can be found in the wider context of political cultures of African countries. Bayart argues that Senegal's Abdou Diouf, Congo-Brazzaville's Sassou Nguesso, and Ivory Coast's Houphouet-Boigny used the adjustment agenda to "recover their freedom of action with regard to a political class and a bureaucracy which had cut loose financially from the

62. Bayart, State in Africa, pp. 10-55.

63. Trutz von Trotha, “C'est la pagaille. Quelques remarques sur l'élection présidentielle et son observation internationale au Togo, 1993”, Politique africaine, 52 (1993), pp. I52-I59, I 52; Piot, Nostalgia for the Future, p. 33. 


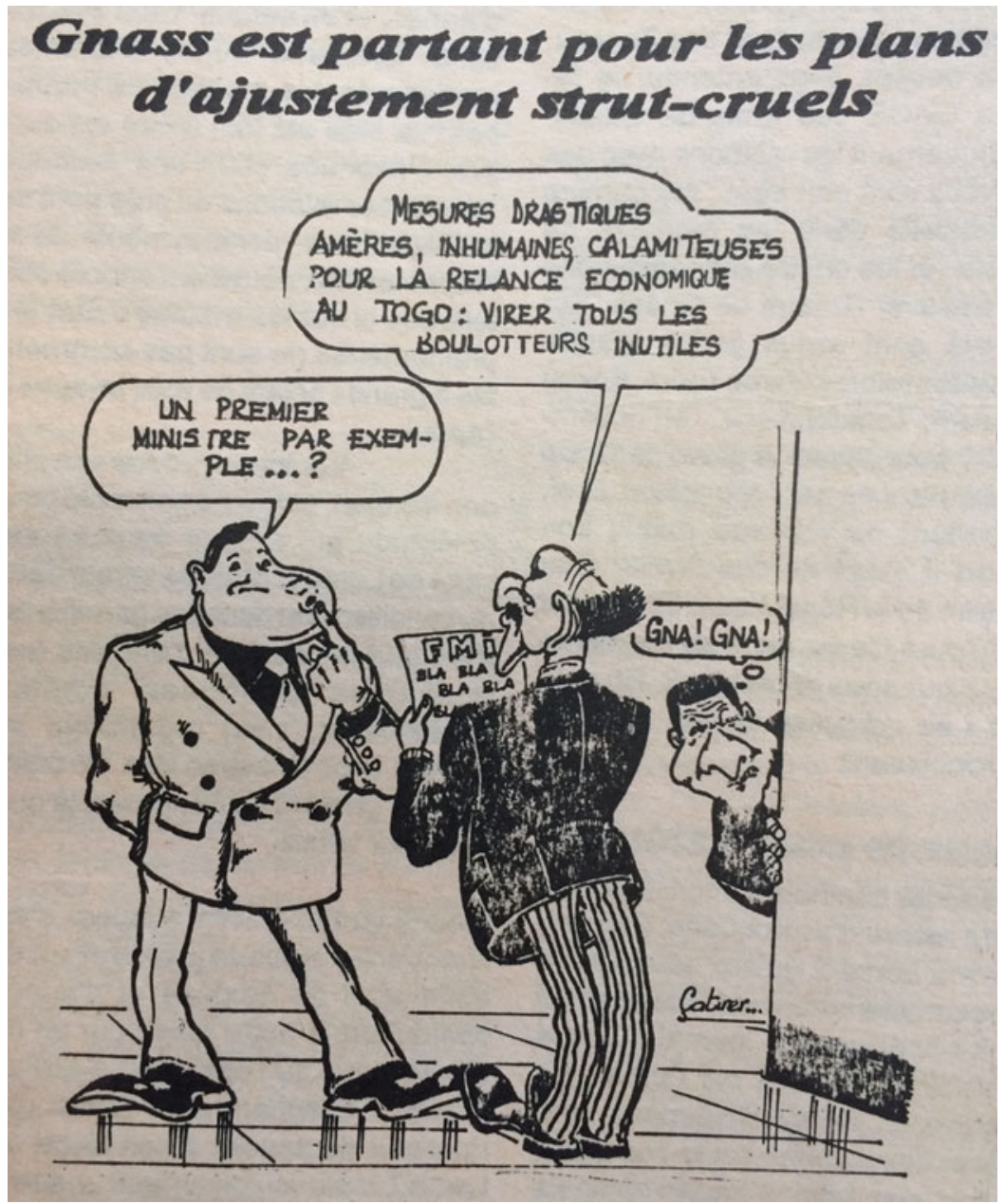

Figure 3. "Gnass est partant pour les plans d'ajustement strut-cruels", Kpakpa Désenchanté (Lomé, Togo) i6 November 1993, p. 2.

centre" ${ }^{64}$ Kpakpa Désenchanté even invented a slogan for a fictive club of African dictators, the "Union syndicale des dictateurs africains". ${ }^{65}$ The newspapers depicted "Gnass" in concert with other presidents such as Mobuto, alias "Mort Bute", or Biya as "CorBIYAr" ${ }^{66}$ However, the cartoonists related this

64. Bayart, The State in Africa, p. 226.

65. Gbanou, "En attendant le vote", pp. 5I-75, 67.

66. Roughly translated these onomatopoeic puns mean "Death Blow" [Mort Bute] and Strange Raven [CorBIYAr], cf. Gbanou, "En attendant le vote", pp. 5I-75, 74. 
dictator's club to French politics. The neologism "Francafrique" or "France-à-fric" ("fric" means "cash") frequently appeared in Kpakpa Désenchanté. ${ }^{67}$ One cartoon, published on 7 January 1992, depicted the French president Francois Mitterrand serving money on a tray to the dictators. The caption reads, "Billions for the "demo(lish)cratie" ("démo(lir)cratie").

\section{DEVALUATION FROM NANA BENZ TO NANA TOYOTA}

On i January 1994, the West African Central Bank (BCEAO) devalued the regional currency, the CFA franc, by half its value. This event heightened the already acute sense of catastrophe. ${ }^{68}$ Two days later, La Pagaille published a cartoon of a weeping woman - a Nana Toyota - sitting on bundles of CFA franc banknotes. In the speech bubbles, she blames the "French" and "democracy" for destroying her capital. ${ }^{69}$ The Nana Benz were rich wax-fabric traders well known for driving expensive Mercedes-Benz cars. In the cartoon, the satirists downgrade the women's symbolic capital. They are no longer Nana Benz but Nana Toyota. These women were important economic actors and owned considerable amounts of money. Indeed, the depiction of the crying Nana Benz was a case in point, because the women suffered greatly under the devaluation.

Since the I970s, the Nana Benz benefited from Eyadéma's "unintrusive capitalist-oriented regime".$^{70}$ During the devaluation period, the tense economic situation was further complicated by the reduction of purchasing power. The Nana Benz branded a wax fabric that depicted a dragon as the "wax of devaluation". ${ }^{\text {I }}$ Satirical newspapers underlined the "deathly consequences" of the price explosion. ${ }^{72}$ Moreover, the population lost trust not only in the regulatory authority of the state to provide enough money, but also in its ability to guarantee the value of money. The devaluation profoundly disrupted the belief in monetary stability. ${ }^{73}$ In the following months, a number of public events manifested the state's powerlessness in monetary affairs: On I 3 May 1994, a money transporter belonging to the BCEAO was attacked. A few days later, the head cashier of the BCEAO, who controlled the

67. François-Xavier Verschave, La Françafrique. Le plus long scandale de la République (Paris, 1998).

68. See also Piot, Nostalgia for the Future, p. 42.

69. La Pagaille (Lomé, Togo), I 4 January i994, p. 3.

70. Heilbrunn, "Social Origins of National Conferences", pp. 277-299, 282.

71. Fondation Zinsou, Wax Stories, Bibliothèque Nationale du Bénin (Cotonou, 2019), p. I 30.

72. Kpakpa Désenchanté (Lomé, Togo), 8 March 1994, p. 2.

73. The governmental newspaper Togo Presse published wrong information concerning the level of the devaluation. First announcements said that the currency would be devalued by sixty per cent. Togo Presse (Lomé, Togo), I 2 January i 994, p. 2. 
transport, was murdered in the streets of Lomé. ${ }^{74}$ At the end of 1994, the Central Bank introduced new banknotes, which were supposed to contain better protection against counterfeiting. However, Kpakpa Désenchanté reported that counterfeited I0,000 CFA franc notes appeared more than ever before. ${ }^{75}$

The everyday experiences with counterfeit money and the apparent incapacity of the state to manage economic affairs reflect a greater conflict in the politics of liberalization. The World Bank and the IMF perceived the French monetary policy in the franc zone as the last stronghold of state interventionism. ${ }^{76}$ This protectionist position contradicted the liberal free-trade doctrine that dominated the international financial institutions in the r 990 s. World Bank and IMF reports argued that the "overvalued" CFA franc was obstructing the adjustment. ${ }^{77}$ For once, the cartoonists and the international financial institutions agreed in their criticism of the currency. The cartoonists perceived the CFA franc as a "fake currency" that served only French interests. ${ }^{78}$ French Minister of Cooperation Michel Roussin was renamed "Minister of re-cooperation and devaluation". Ironically, he was the first to accuse Eyadéma of electoral fraud. Shortly after suspending French development aid for Togo, Roussin was accused of corruption himself, and had to resign. Kpakpa Désenchanté published a cartoon showing the "dictator's club" offering Roussin "devalued" banknotes to hide. Roussin refused "the black money" ("l'argent noir"), yet stood nakedly in front of the dictators.

After the devaluation, the new banknotes were christened "billet Koffigoh" in the streets of Lomé. ${ }^{79}$ Criticism of Eyadéma was absent. In fact, Koffigoh was as powerless as Eyadéma in the diplomatic arena of the franc zone. However, Eyadéma could profit from the situation by blaming his unpopular prime minister. ${ }^{8 \circ}$ The "loss of hope and of a sense of political possibility" reinstated Eyadéma’s hegemony. ${ }^{8 \mathrm{I}}$

74. The transport from Lomé to Abidjan contained the record amount of 9.5 billion CFA francs (approximately is million Euro), Kpkpa Désenchanté (Lomé, Togo), 2 I June 1994, p. 2.

75. Kpakpa Désenchanté (Lomé, Togo), 22 November 1994, "Affaires de faux billets", p. 4.

76. Claude Freud, "La zone franc est-elle le bouc-émissaire de l'échec du développement?", Cahiers d'Études Africaines, 3 I (1991), pp. I 59-174, I70.

77. World Bank, Un programme d'action concerte pour le développement stable de l'Afrique au sud $d u$ Sahara (Washington, DC, 1985); International Monetary Fund, Theoretical Aspects of the Design of Fund Supported Adjustments Programs (Washington, DC, 1987).

78. Kpakpa Désenchanté (Lomé, Togo), is July i 994, p. 4.

79. Many thanks to Essohanam Batchana for sharing this information with me (Lomé, 2019).

80. Toulabor, Togo sous Eyadéma, pp. I4I-158. Eyadéma had already criticized the lack of sovereignty and control in the monetary system of the CFA franc in 1972. Anti-French and antiimperialist rhetoric was in vogue after the Sarakawa incident and the question of privatizing the phosphate company.

81. Piot, Nostalgia for the Future, p. 34. 


\section{GOOD GOVERNANCE” AND THE NEWSPEAK OF THE SAP}

Political analysts have shown that most African rulers have managed "to adjust to adjustment". According to the argument formulated by Patrick Chabal and Jean-Pascal Daloz, the SAPs did not undermine the patrimonial foundations of the state but changed the functioning. ${ }^{82}$

The SAPs represented a "blessing in disguise" because the African rulers could "extract a level of foreign aid which otherwise would not be available". ${ }^{3}$ The cartoons depicted the political elites as sharp operators who used the reform process to their own advantage. The fraudonomics of the adjustment was thus a productive form of offering "distinct financial possibilities for currency-strapped and insolvent states". ${ }^{84}$

The novelty of the mid-1990s was the blaming of extra-state actors in the cartoons, such as French businesspersons. The new prime minister Edem Kodjo, nicknamed "Roi Koq-Djo" or "Sa Koqueteraie", was associated with a "mafia of privatization". ${ }^{85}$ Kodjo was governor of the IMF from 1967 to 1973 and minister of economy and foreign affairs during the I970s under Eyadéma. His relations to the French economic and political elite meant it was thought he was in favour of the privatization of the country. Kodjo was "selling the country" by putting it into a World Bank sack. Other cartoons showed him receiving suitcases full of money from the French prime minister and the company Bouygues. ${ }^{86}$

Money, a constant element of the cartoons, was no longer held in Eyadéma's hands. The "patrimonial ostentation" (Figures I \& 4) included a larger political and economic elite. ${ }^{87}$ Neologisms such as "belly-cracy" (ventro-cratie), big bellies, or other symbols of wealth such as cigars and oversized chairs, referenced the unequal distribution of wealth. ${ }^{88}$ The tensions between the rich and the poor, the powerful and the powerless, were apparent for example in a cartoon that showed a fictive conversation between Prime Minister Kodjo and a World Bank official. Kodjo asks the "Death Bank" (the Banque Mort-diale) what the Togolese government should do if privatization does

82. Patrick Chabal and Jean-Pascal Daloz, Africa Works: The Political Instrumentalization of Disorder (London, 1998), p. I22; Jean-Francois Bayart, Stephen Ellis, and Beatrice Hibou, The Criminalization of the State in Africa (Melton, 1999), p. I 26.

83. See Paul Nugent, Africa Since Independence (London, 2012), p. 338, and Nicolas Van de Walle, African Economies and the Politics of Permanent Crisis, 1979-I999 (Cambridge, 200I), pp. I $52-172$.

84. Janet Roitman, Fiscal Disobedience: An Anthropology of Economic Regulation in Central Africa (Princeton, NJ, 2004), p. 20.

85. These nicknames refer to Kodjo's relations to France, where he lived for many years and taught at the Sorbonne University. The "mafia of privatization" appeared in Kpakpa Désenchanté, 24 April 1995.

86. Kpakpa Désenchanté (Lomé, Togo), I 8 May I994, p. 5; Idem, 24 April I995, p. 7.

87. Chabal and Daloz, Africa Works, p. 160.

88. Kpakpa Désenchanté (Lomé,Togo), 24 April I995, p. 3. 


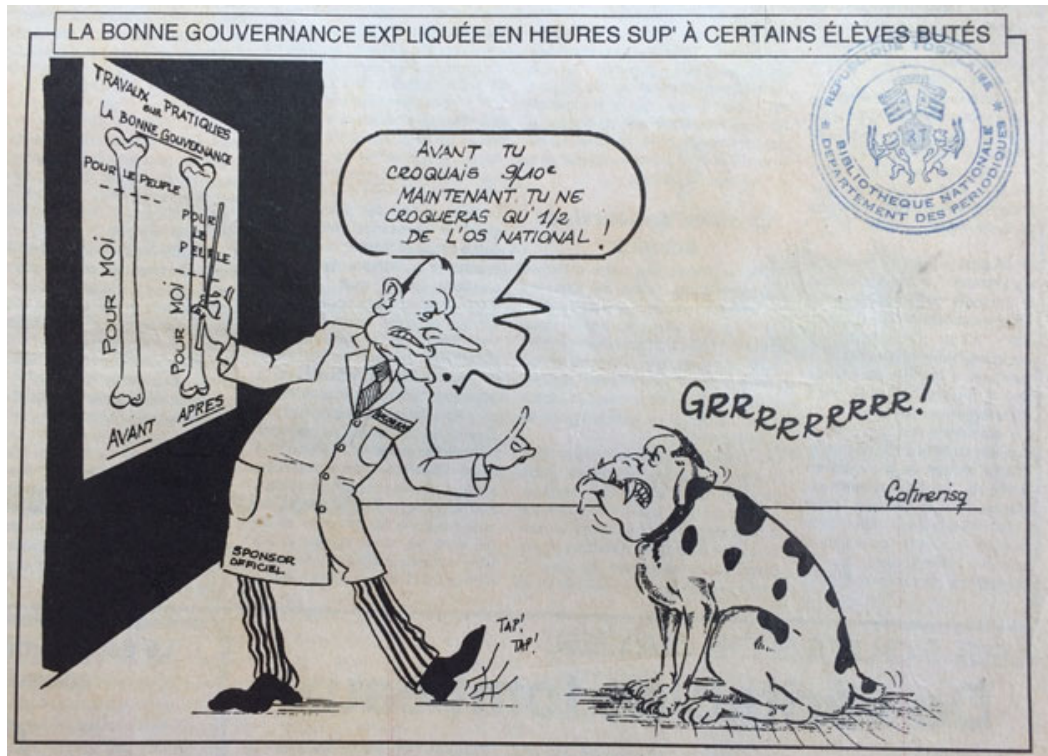

Figure 4. "La bonne gouvernance expliquée en heures sup' à certains élèves butés", Kpakpa Désenchanté (Lomé, Togo), io December i996, p. 3.

not improve the economic situation. The diplomat of the World Bank answers drily: "Privatize the Togolese people". ${ }^{89}$

In Figure 4, Eyadéma is depicted as a voracious dog with bared teeth. He watches as the French president Jacques Chirac points at a board. On it is written, "Practical work for good governance". Underneath these words is a chart that consists of two bones. Each bone is divided into separate portions - one "for the people" and the other "for myself". Eyadéma is angry because he will lose a significant bit of the "national bone". Chirac, the teacher, explains: "In the old days, you could eat 9/ Io of the 'national bone' but now you can only bite half of it." In this lesson of fraudonomics, Eyadéma seems to obey the French president. As the inscription on his clothes indicates, Chirac is the "official sponsor" of Togolese politics. Despite the growling of the dog, Chirac's authority is uncontested.

During the I990s, the phrase "good governance" became increasingly popular with the SAP. In the cartoon, Chirac no longer advocates for democracy as his predecessor did in 1990 at La Baule, but rather for good governance. In line with several other puns on the technical and political language of the adjustment, the concept of "good governance" represents another illustration of fraudonomics. The cartoonists hint sarcastically at the Newspeak of the 
adjustment. Togolese officials integrated the rhetoric of the World Bank, IMF, and international donors into political communication. The journalists made puns on abbreviations, country rankings, or the use of arbitrary indicators. ${ }^{90}$ In contrast to the Newspeak of the adjustment, the satirical newspapers used colloquial language or imitated wrong pronunciations. According to Orwell's definition, Newspeak contains no negative terms. For example, the only way to express the meaning of "bad" is through the word "ungood", while something extremely bad is called "doubleplus ungood". ${ }^{\mathrm{I}}$

The animalization of the president as a salivating dog with pointed teeth was a figurative expression in many caricatures of the time. It also calls to mind George Orwell's Animal Farm, where the dogs are guards of the dictatorship..$^{92}$ The bone on the board illustrates the president's greed for the public budget. In contrast to Eyadéma's self-presentation as a charismatic peacemaker and father of the nation, the bloodthirsty dog was a common figure of speech that was used by regime opponents to denounce Eyadéma's personified propaganda. ${ }^{33}$ The anthropomorphism might also be understood as revenge following the dehumanization of his dictatorship. Eyadéma's cult of hunting and nature preservation remained in the collective memory. ${ }^{94}$

\section{CONCLUSION: FRAUDONOMICS AND CONTESTATION TODAY}

This article has argued that cartoons fulfilled a political need in a time of acute disorientation. Cartoons perceived the structural adjustment and the authoritarian restoration as fraudonomics. They targeted the president, local politicians, businesspeople, and bureaucrats of the SAP institutions. The oppositional cartoons crisscrossed the economic and political sphere. Many cartoons testified the moral implications of the changing institutions and economic measures. Regarding the moral economy of the "adjustment people", this article has shown that the protests involved a much larger variety of actors and topics than expected.

This article has shown that the criticism of the early I990s significantly destabilized the moral authority of the regime, which had to invent new

90. TVA (Taxe sur la Chaleur Ajoutée), Kpakpa Désenchanté (Lomé, Togo), i 8 July i995, pp. 46; BM ("Banque Mortiale” or PAS ("ça ne passe pas"), in Frère, Presse et démocratie, p. 269; "Togo as Last Country on the List of the IMF but also of Amnesty International”, Kpakpa Désenchanté (Lomé, Togo), i 8 May i995, p. 5.

91. George Orwell, Nineteen Eighty-Four (London, 2007), pp. 338-339.

92. Orwell, Animal Farm, p. i 2.

93. Toulabor, Le Togo sous Eyadéma, pp. I 2 I-I 25 , 300. Regime opponents named the president Avusu, meaning angry male dog in Èvegbe.

94. This representation is stressed in the novel by Ahmadou Kourouma, En attendant le vote des bêtes sauvages (Paris, 1998). 
ways of legitimization. One must note that this period was a productive and creative moment in the demystification of Eyadéma's regime, which was also depicted in novels and theatre plays. For example, the writer Ahmadou Kourouma, who lived in Togo from I 984 to I994, critically engaged with Eyadéma's biography and caricatured Eyadéma as the fictional President Koyoga. ${ }^{95}$ A number of Togolese writers such as Kagni Alem, Kossi Efoui, and Sami Tchak, who all became famous for their literary works in the I990s, were similarly successful in making the "real visible". ${ }^{96}$

However, a question remains: why did these critical discourses lose their contentious power? In terms of criticism, the period analysed in this article was one of liberalization. Yet, there is still a desperate need for the imagination of political alternatives in Togo, where Eyadéma's son Faure Gnassingbè has been in power since 2005. The current opposition press significantly lost both its quality and influence. Instead of the numerous satirical newspapers that existed during the I990s, only one publication (SIKA'A) remains; although it seems quite isolated, monotonous, and futile in its denunciation of "Small Boy", the nickname of the current president. The former cartoonists and journalists interviewed for this article all live abroad, and work as fine artists, researchers, and consultants. Why did they stop denouncing the fraudonomics? The satirists faced the question of how to adapt to the changing political and economic landscape when the regime either conscripted or expelled any criticism. Today's situation shows a paradox of liberalization. It has never been as easy as it is now to express criticism, considering the vast landscape of social networks; so why does the liberalization of the media space not enable more liberated satirical protest?

95. Kourouma, En attendant le vote, p. 368.

96. Kangni Alem is a writer and founder of Atelier théâtre, Kossi Efoui was a leading activist and playwright during the I990s, and Sami Tchak is a writer and sociologist. 